\title{
Autonomous Learning through English Listening Apllication
}

\author{
Winantu Kurnianingtyas Sri Agung \\ IAIN Ponorogo, Jl. Pramuka 156 Ponorogo, East Java, Indonesia
}

\{winantu.kurnianingtyas@gmail.com\}

\begin{abstract}
The key concept in communication is listening since lack of ability in listen accurately; communicants are not able to catch the message easily. ESL learners should aim to master one of communication skills, that is listening. As the result, teachers must concern on students' capability in listening and students as second language learner have to develop their listening skill both inside and outside classroom. An interactive and effective media should be applied in improving listening skills of ESL learners. In interface digital age, teachers are required to explore application technology in listening chore. English listening is one of appropriate application to teach English listening because it assess easily in both students and teachers' Smartphone. English listening is recommended for ESL learners in university level since it is constructed into three different levels namely beginner, intermediate, and advanced. Furthermore, this application consists of various types of exercises. Through this application, students are able to improve their listening skill and teachers can manage their students' progress in listening.
\end{abstract}

Keywords: Autonomous learning, listening, English Listening

\section{INTRODUCTION}

Technology is used to be mostly familiar in recent day in teaching and learning of second language class. Both teachers and students must be aware in exploring modern technology since the its usage in teaching and learning second language improves teachers' instructional process and facilitates students` learning process [1], for instance Mobile-Assissted Language Learning (MALL). In line, MALL promotes interactivity, collaboration, and engagement in various learning activities and personalize learning by giving learners control over what, where, when, and how they will learn, and create a sense of community [2]. On the other word, using MALL in teaching and learning is more effectively by force of time and place. Teachers and students do not usually meet at class face to face but they also are able to do teaching and learning process outside through this technology.

Furthermore, MALL can be accessed in five platforms namely pocket electronic dictionaries, personal digital assisstants (PDAs), mobile phones, MP3 players, and ultraportable tablet PCs [3]. Among those platforms, mobile phone is accessible and familiar in EFL learning since students mostly use this device as communication tool daily. Hence, mobile phone is applicable in improving students' language capability. 
Listening is one of English skill which the students are able to practice as second language learners because over 50 percent of the time that students spend functioning in foreign language will be devoted to listening [4]. In learning second language, through listening, students are going to learn the way in pronuncing and stressing the sound then try to interprete the meaning to understand the message they convey. As that reasons, listening becomes the main of communication that influence the communicants in understanding the message to avoid misunderstanding and distinctive interpretation. To enrich that goal, the second language learners have to improve their ability in listening skill.

In fact, learners mostly assume that listening is difficult subject because of some reasons such as they have to catch the information as the same time as understanding the context, spoken language has different terms with written language in pronunciation, intonation, stress, juncture and so forth. Beside that, traditional learning material and technique in teaching listening are almost used by teachers eventhough today is in digital era. As the consequence, learners have eager in improving their listening ability yet.

To overcome those problem and to enrich the goal of listening, technology such as mobile phone device is needed in EFL teaching and learning process. This device facilitates EFL learners in listening inside classroom and achive second language learners independently in learning listening. Autonomous learning are expected to take responsibility for students in learning [5]. In line, Littlewood mentioned two central features of autonomy firstly students are expected to take responsibility of their learning and secondly taking responsibility involves learners in taking ownership of their learning [6].

To built up students conciousness in learning listening, mobile phone device is chosen since the students use mobile phone in their communication daily. Therefor, they can access to authentic listening material and increase their auotonomy in learning. As the fasilitator and also teacher, the researcher chose English Listening application because of some reasons firstly this application was created for both beginners and advanced English learners. Secondly, it has varios types of exercises for instance filling the blanks, identifying pictures, rearranging sentence, listening to short passages, dictation, listening to long paragrph (monologue). Thirdly,the types of exercises is similar with some test types in TOEFL and TOEIC. Fourthly, the subject of this research took intermediate listening as preparation class in interface TOEFL and TOEIC test like. Thus this research describe the implementation of English Listening Application in built up EFL college students' consciousness in learning listening upon the class activity through five developmental components in emphasizing autonomy of students learning [7].

a. determining the objectives

b. defining the contents and progressions

c. selecting methods and techniques to be used

d. monitoring the procedure of acquisition properly

e. evaluating what has been acquired

\section{METHODOLOGY}

\section{a. Research Design}

Qualitative descriptive were conducted in analyzing autonomous learning of second language learners in listening class through English Listening Application. Huberman argued that researcher preserves chronological flow, see precisely which events led to which consequences and derives fruitful explanations [8]. In this case, the researcher explored 
mobile phone application towards learners in order to make learners aware of the language capacity improvement.

\section{b. Subject}

Participant in this research was English students of teacher training department at IAIN Ponorogo. They were fourth semester and taken intermediate listening class. As the consideration, the researcher took $\mathrm{C}$ class became the subject in this research since the learners varied from educational background such senior high school, Islamic boarding school, Islamic senior high school, and vocational high school. Furthermore, based on their listening rating scale in previous semester showed that they were different levels of rating scale namely super, going beyond, meets the mark, and needs more work than other class.

\section{c. Instruments}

This study employs data of observation and documentation. In collecting the data, classroom observation was conducted to know how the learners apply English Listening Application. The observation focused on observing students' activities and their autonomy in learning listening in using that application and completing the teacher's tasks. Meanwhile, documentation was in terms of photos and videos during teaching and learning process in listening class. Those enquired students' activities.

\section{d. Data Analysis}

According to the nature of the research, the study used phenomenology as the analysis method. All collected data were clarified clearly as the purpose of this research in describing the autonomous learning in listening class through English Listening Application based on the researcher experience in listening class. In line with Lofland phenomenology is used to describe the researcher's experience and the idea that this is all research is or can ever be [9].

\section{FINDINGS AND DISCUSSION}

\section{a. Teaching Listening procedure using English Listening Application}

In this research, the Listening class was Intermediate listening of forth semester students. English lecturer used English Listening Application as a mobile phone device to give listening materials and board discussion to the learners. First, lecturer asked the students to open play store in their mobile phone. She suggested downloading thus application 


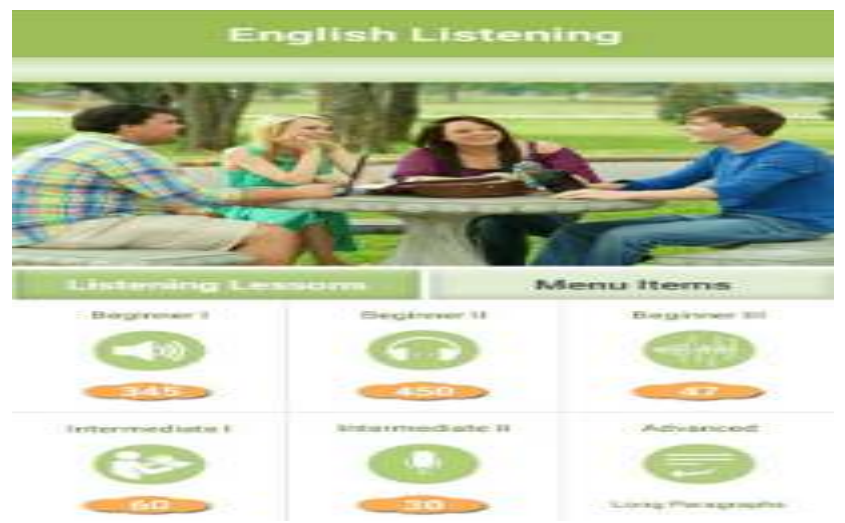

The researcher gave the clear objectives of the activities and the lecturer's instruction must be followed by the students. They should be as follow indicators

1. Students are able to analyze meaning each types of text that they listen

2. Students are able to decide their own learning strategy independently in listening class

3. Students are able to do exercises

After downloading the application, students are asked to decide their own learning strategy in accomplishing the exercises. In this step, the researcher explained about the types of exercises that the students have to complete. The exercises were created in 6 different levels of difficulties. Each level of exercises consists of 30 numbers of questions.

It is the first level called beginner I. Here, the students should fill the blanks with the appropriate words based on the audio. To answer correctly, the students have to drug the correct word into the blank space.

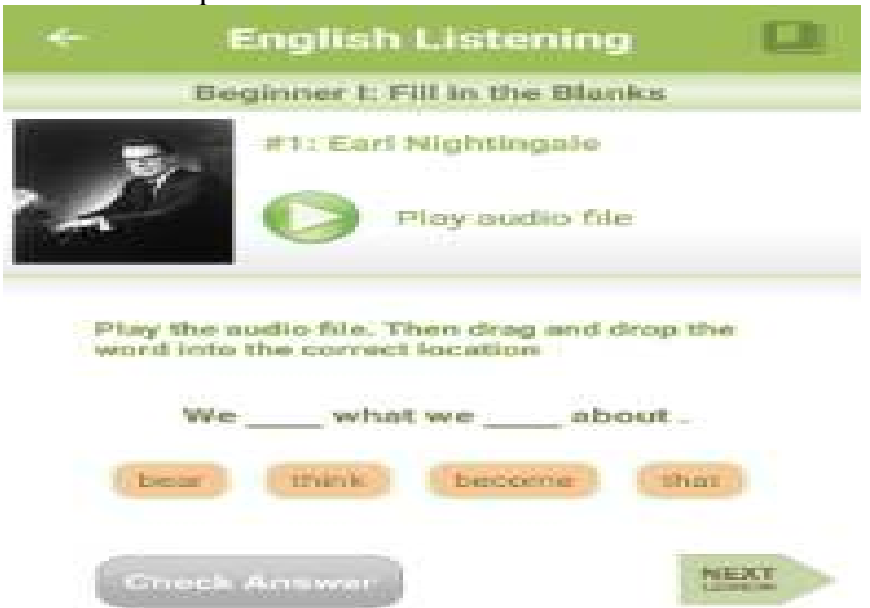

The following is the second level namely beginner II. In this exercise, the students chose the best answer by identifying the picture. The students can choose the answer by click A, B, C or D. 


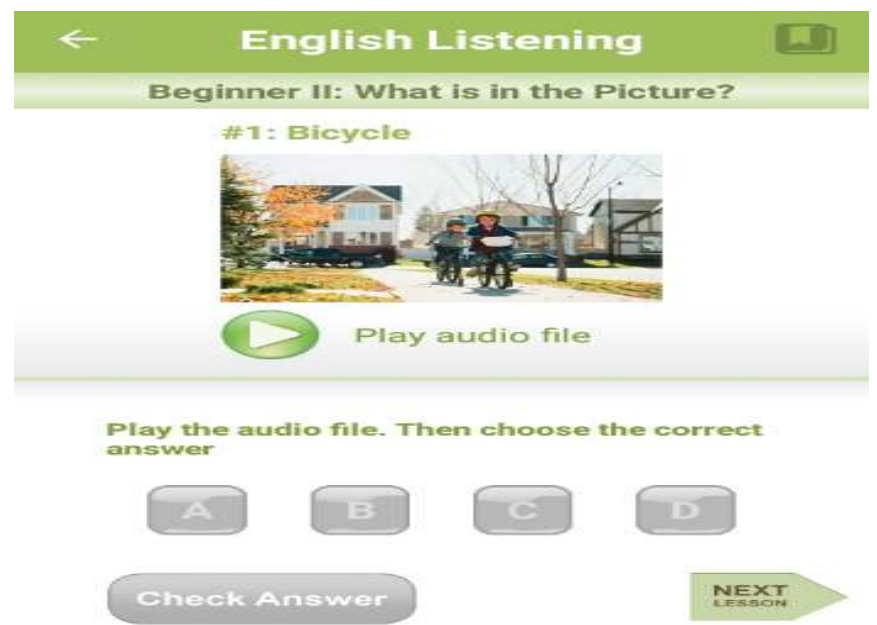

The third exercise is beginner III. The students have to rearrange the quotations that they listened. In completing the quotation, the students must drug the words into the blank space.
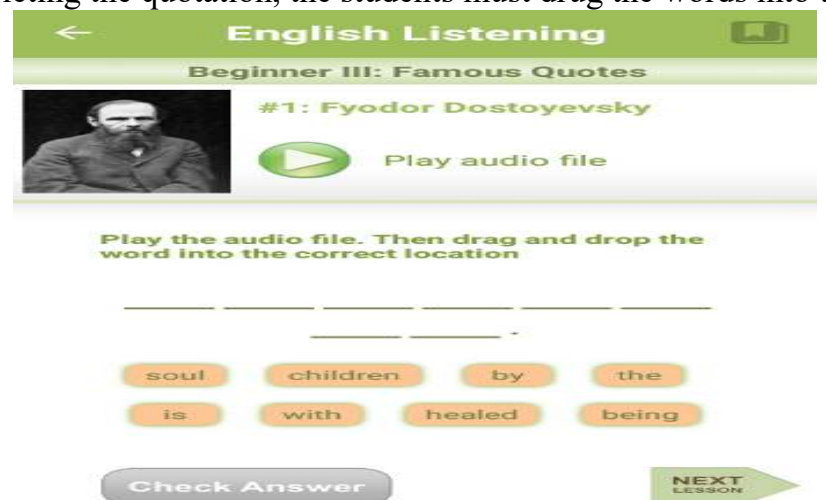

Intermediate I become the fourth exercise. Here, the students listened to the short talk and the exercise discussed about the main idea of each talk.
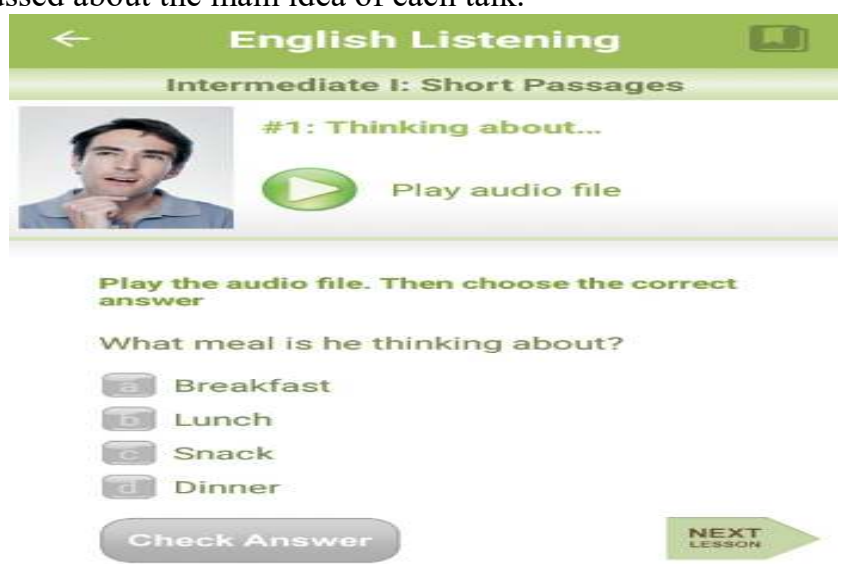

The fifth task is intermediate II. The students rewrote the audio file that they have been heard in the column. 


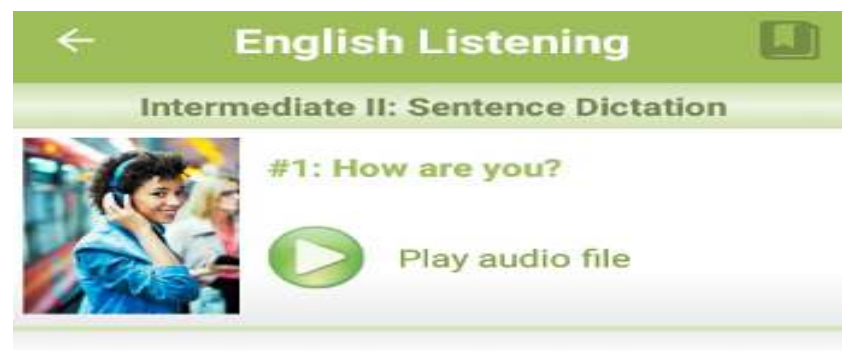

Play and listen to the audio file. Then write what you hear.

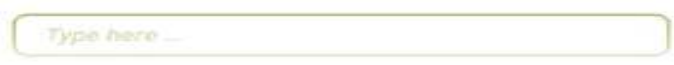

\section{Check Answer}

Advanced becomes the last level of task in English Listening application. In this case, the students listened to the talk to answer several numbers of questions.

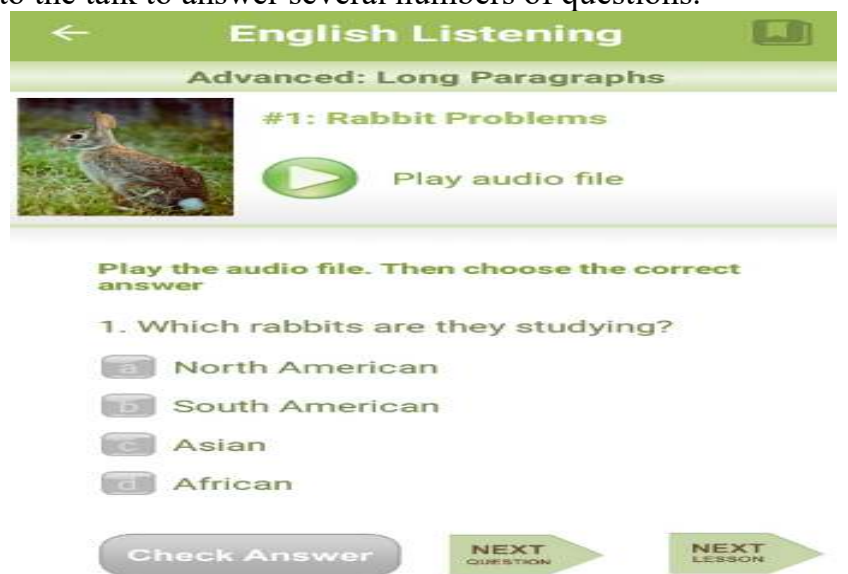

The next direction was given by the researcher to the students about gaining the points in all tasks. Easy lessons are given less points while harder ones are given more points. For instance, lesson \#1 is only worth 5 points, while lesson \#30 is worth 20 points. Then, the points are less if the students listen to the audio file many times, for example lesson \#1 5 points is given when the students listen to the audio file one

3 points is given when the students listen to the audio file twice

1 point is given when the students listen to the audio file many times lesson \#30 20 points is given when the students listen to the audio file one

15 points is given when the students listen to the audio file twice

7 points is given when the students listen to the audio file many times The points next to the lesson are the number of points for that lesson.

After describing the roles and the point, the students have a chance in determining the way they learn in listening class by using English Listening application

b. Emphasizing Autonomy of Students Learning in Listening Classroom Activities 
In describing learning autonomy in listening class, the researcher applied five developmental components and explained clearly in each single steps as follow

1. Determining the objectives

Teacher explained the aims of intermediate listening class by using this application and the students showed their awareness about the understanding of course requirements and they also showed their own efforts in learning listening.

2. Defining the contents and progressions

Identifying content in learning based on the learners' choice has been strong effect in learning autonomy [10]. In this case, the researcher as the lecturer here gave clear instruction and introduced the contents of English Listening application and the students decided the level of exercises they would be taken self to completing all exercises.

3. Selecting methods and techniques to be used

According to James \& Garret, in order to help learners to assume greater control over their own learning. it is essential to help them become aware of and identify the strategies that they already use or could potentially use.

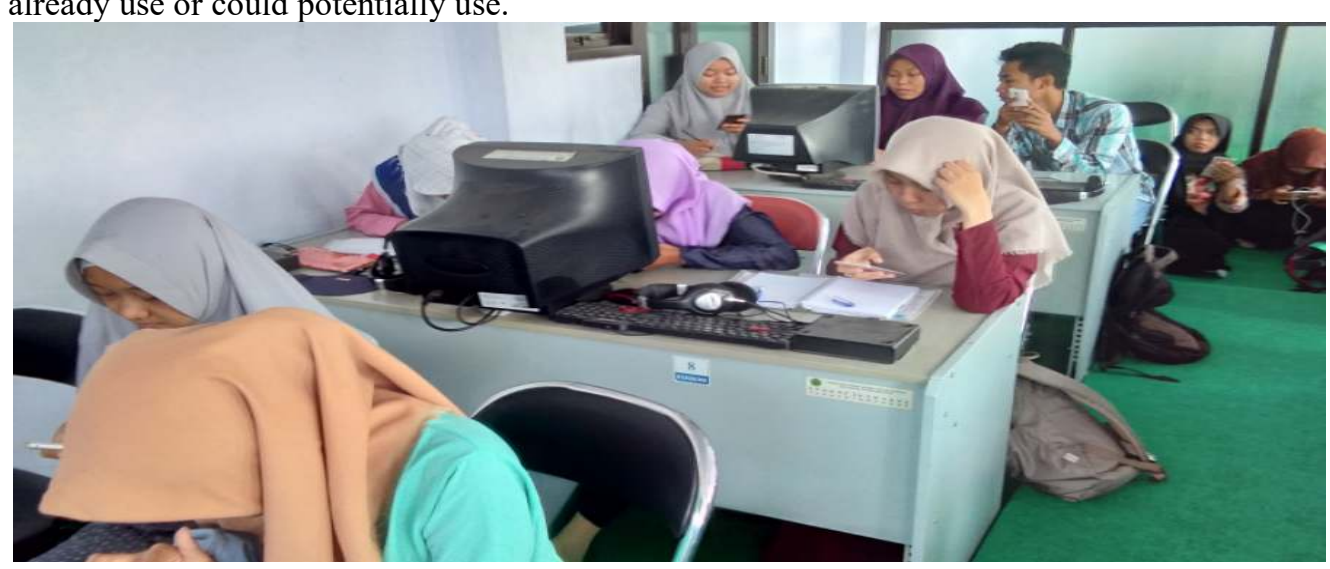

Here, the lecturer gave a chance toward the students to explore the way they learnt by discussing with friends or doing the exercises self. The aim was development students' awareness in learning listening.

4. Monitoring the procedure of acquisition properly

In this research, the students are able to monitor their own progress, performance, finding opportunities outside class and cooperation with friend. The students have to accomplish the exercises due to the required time. Beside in class, they can do the exercises whether in class or outside class.

5. Evaluating what has been acquired

Self assessment and evaluating their own learning process are essential components of autonomous learning, enabling learners to undertake more responsibility and identifying their weak and strong areas as well as effective language learning strategies and materials [11]. To see the progress of learning process, the lecture asked the students to show their score of when they finished doing each level of exercises. In the end of this program, the students have to present their weakness and strengthen in learning process using this application. 


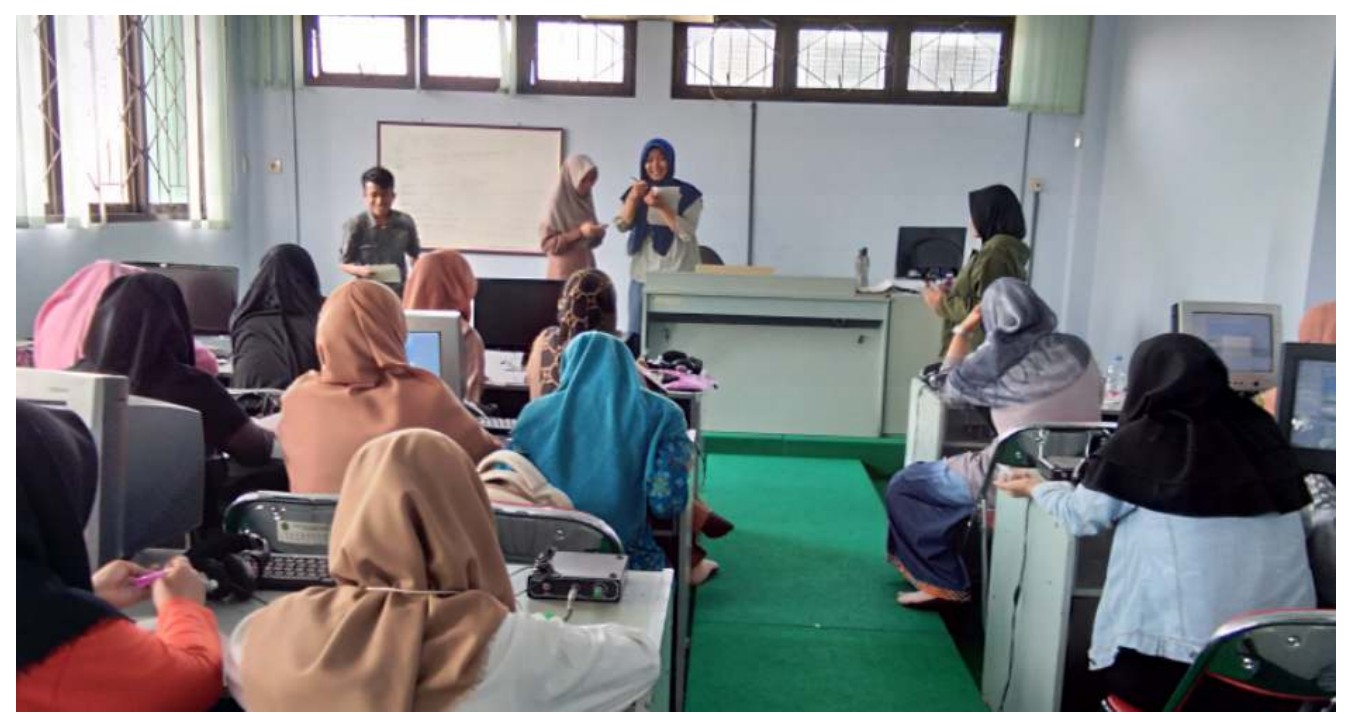

\section{CONCLUSIONS}

The study revealed that in implementing English Listening application to stimulate students' autonomous learning, lecturer make certain teaching procedures by giving the objectives of learning listening, introducing the contents of thus application, and explaining the points or score. Then the implementation of English Listening Application in built up EFL college students' consciousness in learning listening upon the class activity through five developmental components in emphasizing autonomy of students learning namely determining the objectives, defining the contents and progressions, selecting methods and techniques to be used, monitoring the procedure of acquisition properly, and evaluating what has been acquired

\section{Acknowledgements}

I gratefully thank my students of English Teacher Training Department in intermediate listening class for the help in conducting this research. Then my heartfelt thanks for my collegues for enduring my endless talks about this research and supporting comments.

\section{References}

[1] Ismail Yaman et,all. Current Trends in ELT. Turkiye: NUANS Publishing. 2016. pp 171.

[2] Kukulska-Hulme, A. Will Mobile Learning Change Language Learning? European Journal for Computer Assisted Language Learning, 21 (2), pp 157-165. 2009.

[3] Trinder J, Mobile Technologies and Systems in A. Kukulska Hulme \& J. Traxler (eds), Mobile Learning: A Handbook for Educators and Trainers, pp. 7-24. 2015. London: Routledge.

[4] Nunan D, Approaches to Teaching Listening in the Language Classroom in I. S. P. Nation and Jonathan Newton Teaching ESL/EFL Listening and Speaking, pp 37. 2009. 
New York: Routledge

[5] Gulten Genc, “Autonomous Learning Capacity of EFL Student Teacher," International Journal of Languages' Education and Teaching., vol. 3 no. 2, pp. 23-42. 2015.

[6] W. Littlewood, Defining and Developing autonomy in East Asian Contexts in Gulten Genc, "Autonomous Learning Capacity of EFL Student Teacher," International Journal of Languages' Education and Teaching., vol. 3 no. 2, pp. 23-42 . 2015.

[7] Holec, H. Autonomy in Foreign Language Learning in David Little "Learner Autonomy and Second/Foreign Language Learning. 2003.

[8] Matthew B. Miles and A. Michael Huberman, Qualitative Data Analysis: An Expanded Sourcebook, $2^{\text {nd }}$ ed, pp 1. 1994. California: SAGE Publications.

[9] John Lofland and Lyn H. Lofland, Analyzing Social Settings, $3^{\text {rd }}$ ed, pp 14. 1995. Belmont: Wadsworth.

[10] Cotteral, S. Developing a Course Strategy for Learner Autonomy. ELT Journal 49 [3], 1995. pp. 219-227.

[11] McNamara, M \& Deane D. Self Assessment Activities toward Autonomy in Language Learning. TESOL Journal, 5. 1995. pp. 18-23. 